\title{
Model Test of Soft Soil Consolidation Based on Surcharge Preloading Combined with Electro-Osmosis Methods
}

\author{
Gang $\mathrm{Li}^{1}$, Jia Liv ${ }^{2 *}$, Tao Luo ${ }^{1}$, Ming Xie ${ }^{1}$, Huanhuan $\mathrm{Li}^{1}$ \\ ${ }^{1}$ Shaanxi Key Laboratory of Safety and Durability of Concrete Structures, Xijing University, Xi'an, \\ Shaanxi 710123, China; \\ ${ }^{2}$ School of Geological Engineering and Geomatics, Chang'an University, Xi'an, Shaanxi 710054, \\ China. \\ *E-mail: 15929935077@163.com
}

doi: $10.20964 / 2021.02 .52$

Received: 13 October 2020/ Accepted: 8 December 2020 / Published: 31 December 2020

\begin{abstract}
In this study, the experiments were carried out to determine the influence of surcharge preloading (SP) combined with electro-osmosis (EO) methods on soft soil consolidation, and the consolidation effect was improved by adding nano- $\mathrm{SiO}_{2}$ particles or nano- $\mathrm{Fe}_{3} \mathrm{O}_{4}$ solution. We analyzed the variation laws of current $(I)$, potential $(U)$, water content $(w)$, water discharge $(V), \mathrm{pH}$, shear strength $(S)$, and bearing capacity $(B)$ in the process of EO. The results showed that as time $(t)$ increased, the $I$ and $U$ in the soil dropped gradually, whereas the $V$ went up. The $w$ and $\mathrm{pH}$ of soil near the anode were lower than near the cathode, while the $S$ and $B$ were larger. Compared with the upper soil, the lower soil featured a higher $w$, lower $S$, and $B$, and without significantly $\mathrm{pH}$ changed. During the process of EO, transverse cracks were found in the soil in the anode region because of severe shrinkage. Under the action of SP combined with EO, the soil was compacted, thereby its strength was improved. Nanomaterials filled the pores between soil particles, and the nanoparticle aggregates reduced the soil pore size and number and thus made the soil more compact. At the concentration of $3 \%$ nano-SiO $2, \mathrm{SP}$ combined with $\mathrm{EO}$ had the optimal consolidation effect on soft soil.
\end{abstract}

Keywords: Soft soil; Nanomaterial; Electro-osmosis; Surcharge preloading; Consolidation

\section{$\underline{\text { FULL TEXT }}$}

(C) 2021 The Authors. Published by ESG (www.electrochemsci.org). This article is an open access article distributed under the terms and conditions of the Creative Commons Attribution license (http://creativecommons.org/licenses/by/4.0/). 